\title{
Late Onset Foreign Body Reaction due to Poly-L-Lactic Acid Facial Injections for Cosmetic Purpose
}

\author{
Yu Jin Jeon, Dae Won Koo, Joong Sun Lee \\ Department of Dermatology, Eulji University Hospital, Eulji University School of Medicine, Daejeon, Korea
}

\begin{abstract}
The safety and efficacy of Poly-L-lactic acid (PLLA) as an injectable facial volumizer for the treatment of lipoatrophy and facial rejuvenation has been widely proven. We experienced a remarkable case of deep-seated nodules on both the cheeks of 57-year-old female 18-months after administration of PLLA filler injection for cosmetic purpose and performed a skin biopsy. With hematoxylin and eosin stain, the nodule showed non-caseating granulomas consisting of histiocytes with central foreign bodies in the dermis. This case report represents the late-onset foreign body reaction due to PLLA facial injections. (Ann Dermatol 32(6) 519 522, 2020)
\end{abstract}

\section{-Keywords-}

Foreign-body reaction, Granuloma, Poly-L-lactic acid

\section{INTRODUCTION}

Correction of aging changes and contour deformities has been a general issue for decades. Various materials have been used as tissue augmentation agents by administering into the tissues. Cosmetic fillers are mainly classified into four categories; the calcium hydroxyapatite-based agent,

Received February 6, 2020, Revised July 30, 2020, Accepted for publication August 4, 2020

Corresponding author: Joong Sun Lee, Department of Dermatology, Eulji University Hospital, Eulji University School of Medicine, 95 Dunsanseoro, Seo-gu, Daejeon 35233, Korea. Tel: 82-42-611-3037, Fax: 82-42-259-1111, E-mail: sun_lee@eulji.ac.kr

ORCID: https://orcid.org/0000-0003-2562-4090

This is an Open Access article distributed under the terms of the Creative Commons Attribution Non-Commercial License (http://creativecommons. org/licenses/by-nc/4.0) which permits unrestricted non-commercial use, distribution, and reproduction in any medium, provided the original work is properly cited.

Copyright (c) The Korean Dermatological Association and The Korean Society for Investigative Dermatology the poly-L-lactic acid (PLLA) agent (Sculptra ${ }^{\circledR}$; Dermik Laboratories, Paris, France), the collagen-based filler with polymethyl methacrylate crystals, and hyaluronic acid-based fillers'.

Considering the stability of PLLA and ease of procedure, PLLA filler injection is often performed for the management of facial aging. PLLA filler has been approved by the United States Food and Drug Administration as the first injectable facial volumizer for the treatment of lipoatrophy in 2004. During the last decade, PLLA filler has been utilized for various purposes such as restoration of lipoatrophy in patients infected with human immunodeficiency virus or correction of facial lines or wrinkles and augmenting depressed parts of the face. The mechanism of action involves the stimulation of collagen and the synthesis of other connective tissues. As the PLLA filler is biodegradable in nature, the duration of correction remains for 1 to 2 years $^{2}$. However, despite its noted efficacy, many side effects have also been reported ${ }^{2}$. Herein, we describe a case of formation of nodules due to foreign body reaction followed by injection of PLLA filler.

\section{CASE REPORT}

A 57-year-old female patient presented with asymptomatic skin-colored firm nodules on both the cheeks, which had persisted for one month. She had a history administration of PLLA filler (Sculptra ${ }^{\circledR}$ ) injection for restoration of facial volume at these sites 18 months back.

Physical examination revealed multiple, bilaterally distributed, well-marginated, round-shaped, and firm skin-colored nodules on both the cheeks (Fig. 1).

Histopathological examination of the cheek revealed noncaseating granulomas consisting of histiocytes with central foreign bodies in the dermis. The translucent, long, and spiky particles were considered as filler constituents lo- 
cated in the foreign body-type multinucleated giant cells. Granulomas were surrounded by chronic inflammatory cells, which were predominantly lymphocytes accompanied by reactive dermal fibrosis. The histopathological features were supportive of foreign body reactions (Fig. 2).

The patient was treated with two courses of $20 \mathrm{mg} / \mathrm{ml}$ triamcinolone intralesional injections in the lesions at a 2-weeks interval. Subsequent to treatment, complete disappearance of the palpable nodules was observed. No recurrence of the lesions was observed for 2 years. We received the patient's consent form about publishing all photographic materials.

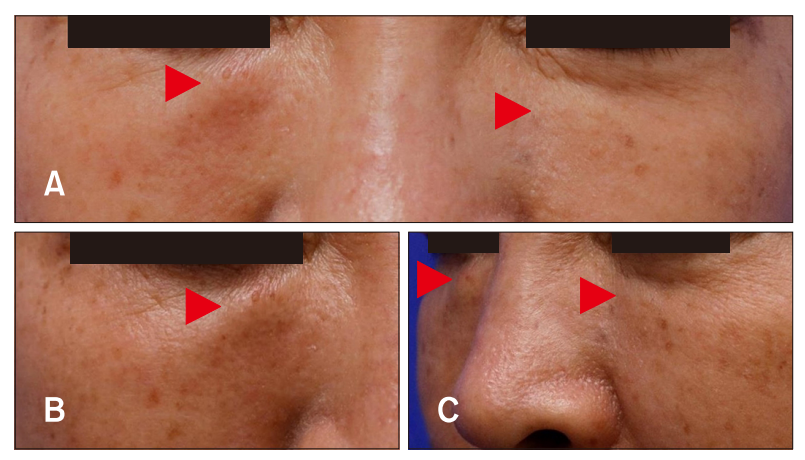

Fig. 1. (A) Skin colored nodules symmetrically distributed on both the infraorbital areas of the face. (B) Close-up view of illdemarcated, oval-shaped, and firm nodules on the right infraorbital area. The right nodule is slightly erythematous to orange colored and larger than the left one. (C) Side view of the lesions which are showing protrusion. Lesions are indicated as red arrowheads.

\section{DISCUSSION}

The PLLA filler is still a commonly used important agent, and it has known to facilitate correction of aging with minimal adverse events ${ }^{3,4}$. The action of the mechanism of PLLA is as follows. After intradermal injection of PLLA, mannitol, carmellose, and xylocaine are reabsorbed rapidly between 24 hours to 3 days, and the PLLA spheres are left behind. Subsequently, the PLLA spheres undergo a process of biodegradation. PLLA is progressively hydrolyzed into monomers or oligomers ${ }^{5}$. Later, the remains of the hydrolyzed products of PLLA are subjected to phag-
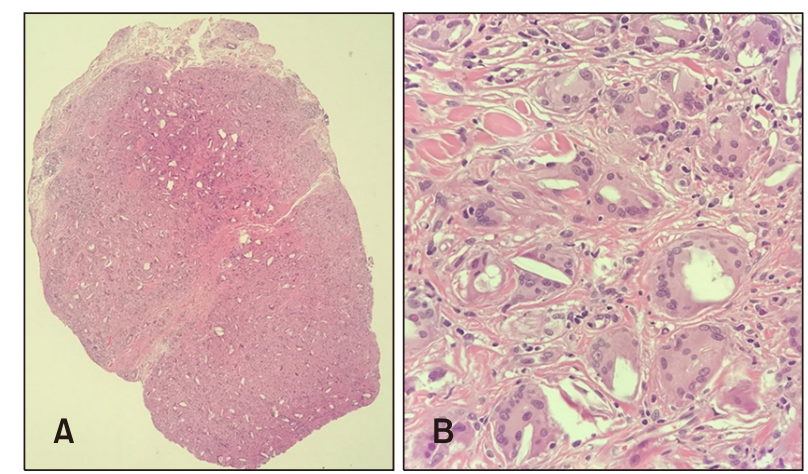

Fig. 2. (A) Histopathologic findings show multiple and scattered polymorphous foreign body reactive to fibrotic change in the dermis $(\mathrm{H} \& \mathrm{E}, \times 40)$. (B) At higher power, non-caseating granulomas consisting of histiocytes, lymphocytes, and multinucleated giant cells with a central foreign body in the deep dermis can be visualized $(\mathrm{H} \& \mathrm{E}, \times 400)$.

Table 1. Summary of reported cases of granulomatous reaction after poly-L-lactic acid injection for cosmetic purpose

\begin{tabular}{|c|c|c|c|c|c|}
\hline No & Study & $\begin{array}{l}\text { Age }(y r) / s e x \\
\text { nationality }\end{array}$ & $\begin{array}{l}\text { Onset duration } \\
\text { after injection }\end{array}$ & Treatment & Site of skin lesion \\
\hline 1 & Apikian et al. ${ }^{4}$ (2007) & $\begin{array}{r}\text { 49/Female, } \\
\text { Australian }\end{array}$ & $6 \mathrm{wk}$ & Surgical excision & Infraorbital area \\
\hline 2 & & $\begin{array}{r}\text { 56/Female, } \\
\text { Australian }\end{array}$ & $7 \mathrm{~d}$ & No treatment & Infraorbital area \\
\hline 3 & & $\begin{array}{r}\text { 57/Female, } \\
\text { Australian }\end{array}$ & $6 \mathrm{wk}$ & No treatment & Intraorbital area \\
\hline 4 & Reszko et al. ${ }^{8}$ (2009) & $\begin{array}{r}\text { 62/Female, } \\
\text { Caucasian }\end{array}$ & $12 \mathrm{mo}$ & $\begin{array}{l}\text { Intralesional triamcinolone injection, } \\
\text { minocycline }\end{array}$ & Intraorbital area \\
\hline 5 & Dijkema et al. ${ }^{14}$ (2005) & $\begin{array}{l}\text { 64/Female, } \\
\text { Netherlander }\end{array}$ & $14 \mathrm{mo}$ & surgical excision & Upper lip \\
\hline 6 & & $\begin{array}{l}\text { 44/Female, } \\
\text { Caucasian }\end{array}$ & $6 \mathrm{mo}$ & Surgical excision & Zygoma region \\
\hline 7 & Kim et al. ${ }^{12}$ (2016) & $\begin{array}{l}\text { 47/Female, } \\
\text { Korean }\end{array}$ & $16 \mathrm{mo}$ & $100 \%$ trichloroacetic acid peel & Lower eyelids \\
\hline 8 & O'Daniel $^{13}(2017)$ & $\begin{array}{r}\text { 50/Female, } \\
\text { American }\end{array}$ & $16 \mathrm{mo}$ & $\begin{array}{l}\text { Oral corticosteroids, } \\
\text { intralesional triamcinolone injection }\end{array}$ & Jawline \\
\hline 9 & Present case & $\begin{array}{l}\text { 57/Female, } \\
\text { Korean }\end{array}$ & $18 \mathrm{mo}$ & Intralesional triamcinolone injection & Infraorbital area \\
\hline
\end{tabular}


ocytosis by macrophages ${ }^{6}$. PLLA acts as a stimulant for fibroblasts, thereby inducing synthesis of new collagen, which produces the cosmetic result ${ }^{7}$.

PLLA use has not always been free of complications. Short-term adverse reactions to PLLA injections reported in the literature include pain, edema, bleeding, ecchymosis, dyschromia, overcorrection, embolism, and localized cellulitis $^{8}$. These side effects usually occur within days after injection and resolve spontaneously within 1 to 2 weeks. There have been cases of PLLA-induced granulomas in both orthopedics and general surgery ${ }^{8-11}$. Persistent palpable subcutaneous papules or nodules at the injection sites characterize intermediate and late adverse reactions ${ }^{1}$. There was one case of paraffinoma that clinically mimicked xanthelasma in both lower eyelids 2 years after PLLA injection ${ }^{12}$. This patient showed well-demarcated yellowish plaque lesion and did not improved with intralesional injection of triamcinolone. Authors said 100\% trichloroacetic acid peel was more effective. Another case of late-onset nodular reaction after PLLA injection was reported in the United States ${ }^{13}$. This late-onset nodules appeared 16 months post-initial injection and took over a year of treatment with oral corticosteroids and periodic intralesional steroid injections for nodules to resolve. Histopathologic examination was not performed in this case. Histologically subcutaneous nodules show deposits of PLLA with scarce inflammatory infiltrate. Late-onset nodules show PLLA fragments in partial dissolution located primarily within the foreign body giant cells and embedded in the fibrous tissue. Fibrosis is generally sparse. Chronic inflammatory infiltrate, macrophages, and variable degrees of necrosis have also been reported ${ }^{8}$. Reported cases of granulomatous reaction after poly-L-lactic acid injection were presented at Table $1^{4,8,12-14}$.

Treatment options for late-onset subcutaneous nodules include intralesional steroids, systemic steroids, systemic antibiotics, intense pulsed light, 5-fluorouracil, allopurinol, and surgical removal ${ }^{8}$. In this case, intralesional triamcinolone $(20 \mathrm{mg} / \mathrm{ml})$ injection was found to be very effective.

There are some reported cases of PLLA filler induced late-onset foreign body granulomatous reaction in Europe and America ${ }^{14,15}$, but there have been rare reports in Korea. In addition, rapid improvement using triamcinolone intralesional injection is notable compared with previous reported cases. We describe the first case of a Korean middle-aged female with the development of multiple nodules, which histologically revealed foreign body granuloma formation following the administration of PLLA into the face for correction of rhytides and contour deformities for educational purpose; successful treatment was observed to be clinically meaningful. It is proposed that suffi- cient warning by the performer before the injection of PLLA filler may be of importance based on the possibilities of occurrence of subsequent complications.

\section{CONFLICTS OF INTEREST}

The authors have nothing to disclose.

\section{FUNDING SOURCE}

None.

\section{DATA SHARING STATEMENT}

Research data are not shared.

\section{ORCID}

Yu Jin Jeon, https://orcid.org/0000-0002-2134-3585

Dae Won Koo, https://orcid.org/0000-0001-8587-0205

Joong Sun Lee, https://orcid.org/0000-0003-2562-4090

\section{REFERENCES}

1. Rayess HM, Svider PF, Hanba C, Patel VS, Dejoseph LM, Carron $\mathrm{M}$, et al. A cross-sectional analysis of adverse events and litigation for injectable fillers. JAMA Facial Plast Surg 2018;20:207-214.

2. Lowe NJ, Maxwell CA, Patnaik R. Adverse reactions to dermal fillers: review. Dermatol Surg 2005;31(11 Pt 2): 1616-1625.

3. Olivier Masveyraud F. [Facial rejuvenation using L-polylactic acid: about 298 successive cases]. Ann Chir Plast Esthet 2011;56:120-127. French.

4. Apikian M, Roberts S, Goodman GJ. Adverse reactions to polylactic acid injections in the periorbital area. J Cosmet Dermatol 2007;6:95-101.

5. Kronenthal RL. Biodegradable polymers in medicine and surgery. In: Kronenthal RL, Oser Z, Martin E, editors. Polymers in medicine and surgery. Boston (MA): Springer, 1975:119137.

6. Zimmermann US, Clerici TJ. The histological aspects of fillers complications. Semin Cutan Med Surg 2004;23:241250.

7. Kim SA, Kim HS, Jung JW, Suh SI, Ryoo YW. Poly-L-lactic acid increases collagen gene expression and synthesis in cultured dermal fibroblast (Hs68) through the p38 MAPK pathway. Ann Dermatol 2019;31:97-100.

8. Reszko AE, Sadick NS, Magro CM, Farber J. Late-onset subcutaneous nodules after poly-L-lactic acid injection. Dermatol Surg 2009;35(Suppl 1):380-384.

9. Mosier-Laclair S, Pike H, Pomeroy G. Intraosseous bioabsorbable poly-L-lactic acid screw presenting as a late foreignbody reaction: a case report. Foot Ankle Int 2001;22:247- 
251.

10. Tannirandorn $\mathrm{Y}$, Tuchinda K. Vaginal vault granulations after total abdominal hysterectomy using polyglactin for vault closure. J Med Assoc Thai 2001;84:693-696.

11. Gammelgaard N, Jensen J. Wound complications after closure of abdominal incisions with Dexon or Vicryl. A randomized double-blind study. Acta Chir Scand 1983;149: 505-508.

12. Kim MW, Park HS, Yoon HS, Cho S. Late-onset complication of fillers: paraffinoma of the lower eyelids clinically mimicking xanthelasma. Ann Dermatol 2016;28:753-756.

13. O'Daniel G. Management of late-onset, recurrent facial nodular reaction after poly-L-lactic (PLLA) injections. J Drugs Dermatol 2017; 16:1297-1299.

14. Dijkema SJ, van der Lei B, Kibbelaar RE. New-fill injections may induce late-onset foreign body granulomatous reaction. Plast Reconstr Surg 2005;115:76e-78e.

15. Daines SM, Williams EF. Complications associated with injectable soft-tissue fillers: a 5-year retrospective review. JAMA Facial Plast Surg 2013;15:226-231. 